\author{
Krzysztof PRENDECKI ${ }^{1}$ \\ Krzysztof REJMAN ${ }^{2}$ \\ Włodymyr DEMCZENKO ${ }^{3}$ \\ Kamil KARDIS $^{4}$ \\ BEÁTA BALOGOVÁ ${ }^{5}$
}

\title{
DIFFERENT APPROACHES TO FANS AND SPORTS ARENAS
}

\begin{abstract}
Fans have self-worths and cells, an awareness of the separatness and an unofficial internals. They constitute the group based on the direct and personal contact, to a large extent are becoming involved emotionally and are identifying with the group. Fans are an interesting research topic. They are hatching for transformations, they are developing and are transforming. They are worrying and colourful, are shocking and fascinate, are arousing anxiety and embarrassment. Probably each of us heard about excesses of fans. Through their proceedings many persons suffered harm because of the health and the life, a personal property was destroyed and public, a public life underwent the destabilization and sports. However fans of the volleyball are completely different, constitute the phenomenon of exemplary supporting undoubtedly. They cause, that the court is changing into the stage performance, but fans, rather than competitors are becoming actors playing main parts. In the present article these colourful elements of supporting will be portrayed, with particular reference to one from best at Europe, of Resovii fans Rzeszów. It seems extremely important, introducing to the complexity of issues the sports consumer which is transforming from the industrial fan into the fan of sports impressions. Of unusually difficult consumer, due to the fact that ambulant fans are among a clientele to matches in case of successes. An issue of perceiving changes which are taking place in the business sphere and the sponsorship, seems very interesting where market rules are obscuring the traditional, fanatical form of supporting, making the buyer of services from the fan, best in the character of passes for the consecutive season of the volleyball.
\end{abstract}

Keywords: Fans, sports arenas, volleyball.

A lot of articles relating to the movement of fans show the increased interest in this aspect by social scientists. The above mentioned topic is under study and is constantly discussed in media, as the behavior of fans leaves much to be desired. We can often read the publications about fans sitting in the stands of stadiums. Mr. Piotrowski divided them into

1 Dr Krzysztof Prendecki, Katedra Nauk Humanistycznych, Wydział Zarządzania Politechniki Rzeszowskiej, e-mail: prend@prz.edu.pl

2 Dr Krzysztof Rejman, PWSTE Jarosław

3 Dr Włodymyr Demczenko, Instytut Badań Regionalnych Ukraińskiej Akademii Nauk, Ukraina

4 Doc. Mgr. Kamil Kardis, PhD, Uniwersytet Preszowski, Słowacja

5 Prof. PhDr. Beáta Balogová PhD, Uniwersytet Preszowski, Słowacja 
consumers, fans and hooligans ${ }^{6}$. R. Kowalski defined them as animals, rowdies, official hooligans, ultras, football fans, fans, fanatics ${ }^{7}$. We can be sure that there are no hooligans in the volleyball, except few cases we are going to mention below. We can easily name the sports where one can see troublemakers - football occupies the first place; but hooligans can be also met in such sports as speedway, hockey or basketball. It often happens that the sport itself, because of its brutality, triggers the appropriate response from the audience. In 1987-1988 there were more fights in NBA than Mike Tyson had ${ }^{8}$. But it also happens that even in such kind of sport as tennis, one can face the inappropriate behavior of fans. During the Australian Open Marcos Baghdatis from Cyprus sang songs against the Turks; during the meeting with Novak Djokovic and Amer Delic there was a fight between Bosniaks and Serbs; the police used tear gases during the match of Fernando Gonzalez and Konstantinos; and tennis supporters from Bulgaria threw flares, used vulgarisms for a professional player Tamarin Tanasugarn. However, the great Polish fans, supporters of Adam Malysh called "małyszomaniacy" threw snowballs at Sven Hannawald in Harrachov.

In the following analysis we will focus on the volleyball. It occupies the second place in the national sport in Poland. The study of the 2012 shows that the first place in sport belongs to football, the number of people interested in football, to a large or very large extent, is 59 percent, and the second place occupies volleyball -37.9 percent ${ }^{9}$. The volleyball, as well as boxing, basketball, athletics, football, handball, ski jumping, tennis and speedway are characterized by popularity, telegenicity and pageantry ${ }^{10}$.

L. Stomma describes a football game in the following way: "Let's start from the fact, that the game itself is connected with legs, the usage of hands is prohibited and results in sanctions against those who use them. (...) Without arms and possibility to use them a person is a cripple not only in the physical sense, but also from social and intellectual point of view. The hands are an expression of our socialization, at least, in its social issue. The leg has the opposite - a pejorative meaning and it is not enough to be a »leg « at school, because paradoxically, it can refer also to the football players who (...) lost the match. Prohibition of hands use with simultaneous apotheosis of legs is so exemplary, it is almost a textbook example of what Michael Bakhtin calls »carnival inversion « or rather »carnival placing the world on head «"11.

Sponsors, players and the interested parties or supporters are interested in volleyball and they consider themselves to be the best in the world. But not everyone shares this opinion. For example, during the Volleyball World League arose the question: "Why the kitsch should be chosen?" The sport fan reports about the mass event: "It was a symbol of sport kitsch! Music, cheer leaders, enjoyment because of the Magiera-Kułaga duo performance (by the way, gentlemen, a great respect for professionalism in what you're doing!), crowded

6 Zob. P. Piotrowski, Szalikowcy. O zachowaniach dewiacyjnych kibiców sportowych, Torun 2000.

7 R. Kowalski, Potomkowie Hooligana. Szalikowcy. Spoteczno-kulturowe źródta agresji widowni sportowych, Toruń 2000, s. 33-35.

8 J. Bryant, Przyjemność widza a przemoc $w$ telewizyjnych transmisjach sportowych [w:] A. Gwóźdź, Media - eros - przemoc. Sport w czasach popkultury, Kraków 2003, s. 155.

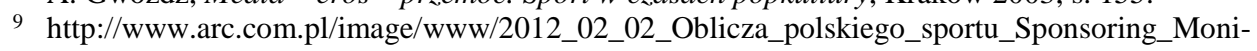
tor_2012_2013.pdf

10 A. Ostrowski, Telewizyjna transmisja sportowa, czyli największy teatr świata, Wrocław 2007, s. 119.

${ }^{11}$ L. Stomma, Futbol dla milionów [w] J. Ciechowicz, W. Moska, Futbol w świecie sztuki, Gdańsk 2012, s. 315-317. 
grandstands, gifts from sponsors, competitions ... Everything is artificially inflated, and the fans are enjoyed even in situations, when their cult figures lose"12.

P. Kovalchuk writes in a similar way about "Viagra for volleyball fans". "The organizers of the European Championship together with a ticket sell for fans a scream, noise, collective dances and songs. The point is not to treat sports event as puritanical devotion in church, but to make sport more important. Many organizers of sport event have another point of view and what is more, pandering to the tastes of crowds, they often turn the event into a festival of trash and kitsch"13.

Kitsch appears to be a bad thing, harmful and trivial, inauthentic, vulgar and artificial, secondary and exaggerated, stamped and biased, exuberant and bombastic. Why kitsch is used together with goodness? Polish situation with great consumer aspirations, small possibilities of satisfying them, cultural promotion of large social groups, traditionalism without culture traditions, especially in everyday life, complexes and snobbery - forms a separate and a very specific situation ${ }^{14}$. In our culture kitsch justifies immaturity, ability and insipidity ${ }^{15}$. In contrary to modern art, common sense (in Latin sensus communis) satisfies the requirements of modern sport ${ }^{16}$. It is an art for everyone ${ }^{17}$. It seems to be dealt with popular art of today ${ }^{18}$. The so-called, "ultras" are of great importance for football. One can find many analogies with bad art on sport arenas: cartons and balloons for children, labado dances, the same capes and fans, use of pyrotechnics to make everything colorful and in order not to see the pitch and the players, bad chants. It's difficult to judge about "ludic" art; only those, who take part in the games can state if they have a lot of fun, when it was worse or better ${ }^{19}$. Kitsch after all "saves us from everyday sadness"20.

The choice of songs and fans chants depends largely on the nature of meeting. In Poland, because of inept music education, both at home and at school, we often face a "roar" of fans. D. Szwarcman drew attention to the voice at the stands, "no melody can be understood. (...). You have to start work concerning studying of good singing. (...). We should not only be seen, but we should be also heard and it shouldn't be any embarrassment" ${ }^{21}$. The composer K. Dębski noted: "We do not know how to tune, sing cleanly and evenly. The people from one side of the stadium interfere with those, who are on the opposite side, because they are in different phases. Even when the national anthem is sung, it is heard that everyone is singing in their own phase and at own altitude; people sing in different tunes and it is created a cacophony of (...) One can hear a roar, which is heard not as a single sound, but

\footnotetext{
12 http://www.sportfan.pl/artykul/sport-na-drugim-planie-fani-kochaja-kicz-a-ty-komentarz-1889\#. strona dostępna 11.03.2013.

${ }^{13}$ P. Kowalczuk, Viagra dla kibiców, „Rzeczpospolita” z 22.09.2013 r., s. 20.

${ }_{14}$ M. Porzęcka, O ztej sztuce, Warszawa 1998, s. 207.

15 J. Burszta, E.A. Sekuła, Smacznego [w:] Kiczosfery wspótczesności, red. J. Burszta, E.A. Sekuła, Warszawa 2008, s. 8.

16 W. Welsch, Sport - przez pryzmat estetyki, a nawet widziany jako sztuka? [w:] Media - eros przemoc. Sport w czasach popkultury, red. A. Gwóźdź, Kraków 2003, s. 326.

17 Ibidem.

18 Ibidem.

19 A. Osęka, Mitologie artysty, Warszawa 1975, s. 121.

20 A. Banach, O kiczu, Kraków 1968, s. 340.

${ }^{21} \mathrm{http}: / /$ szwarcman.blog.polityka.pl/2007/11/18/czas-na-nauke-dopingu/.
} 
as the entire beam of different sounds. Such noise is not only incoherent, but almost soundless" 22 .

The repertoire of Polish national team fans is limited. Such chanting as: "Poland", "White and red are for Poland", "We are with you", "Nothing happened" became the unofficial anthem of the national teams. The chanting is added by an Austrian folk song "Hey Sokoły" and by a song with the action taking place in the Ukrainian steppe, "Pieśn o małym rycerzu", though even the lowest volleyball players of the Polish national team are up to 182 centimeters (Paul Woicki and Michael Zurek).

The most popular hit which can be heard at Polish stadiums during the matches of the Polish national team is our unofficial national anthem "Polacy nic się nie stało." A. Łapicki wrote about the most stupid song of the millennium: "It happened - you lose, accept defeat, but the feisty chorus drowns out with the optimism - Nothing happened ..." (Nic się nie stało). There is no honorary failures, there is no "almost losers" - only winners are right. (...) We have enough beating - we want to win. Who failed - gets whistles $(\ldots)^{23}$. M. Zukowski noted: "The unusual situation in sport that the fans love, despite the failure, perhaps strengthened the volleyball players. It is not the truth that the chanting »Polacy nic sie nie stało « is a hit of football fans. The chanting was initiated in the sport halls of retina and irritated for a long time. While hearing the chanting, the above mentioned Zdzislaw Ambroziak became terribly nervous and explained to fans that it occurred the worst thing the match was lost".

The viewers had different points of view for whistling and humming; for some of them it was an example of boorishness and rudeness, others considered it to be a phenomena inherent in sport competition. The most famous sportsmen suffered. Kazimierz Deyna, a legend of Polish football got a lot of abusive epithets and depressing whistles against him. During the match with Portugal in Silesia in 1977 the captain of the team scored straight from a corner and as a "reward" got some whistles. Maldini who was associated with AC Milan during his lifetime (a football player and captain), won among others, the Italian championship (seven times) or the European Cup (five times), but after the match he got some loud whistles instead of cheers.

After the match Poland - Colombia the players did not blame themselves, but complained about whistling. Artur Boruc even muttered that the supporters behaved as bumpkins. ${ }^{24}$ J. Miodek commented in favour of fans: "I have no pretensions to the fans. One should not be a supporter unconditionally" 25 .

Daniel Olbrychski sent a letter in which he considered the retina supports to be the reason of the beating: "There has not been such situation yet, as it occurred at the Olympic Games. The whole world had a chance to see a shameful behavior of Polish fans in London during the match. It reminded me the Olympic Games in Moscow, where Soviet audience hummed and whistled when Kozakiewicz jumped in rivalry with the Soviet pole-vaulters.

${ }^{22}$ D. Szwarcman (wywiad z K. Dębskim), Wolniej panowie wolniej, „Polityka” z 03.09.2005, s. 64.

23 A. Łapicki, Nic się nie stało, Warszawa 2010, s. 61.

${ }^{24}$ M. Listkiewicz: „Celebryci piłkarscy lubują się ostatnio w dowalaniu innym epitetami związanymi z wioską. „Chłop wyjdzie ze wsi, wiocha z chłopa nigdy” - Jan Tomaszewski o Grzegorzu Lacie. „Żarty Szczęsnego trącą wiochą” - Radosław Majdan o polskim bramkarzu Arsenalu. „Cześć, cześć, cześć - miasto wita wieś” - warszawscy kibice o drużynie z Bełchatowa czy Lubina.

${ }^{25}$ P. Zawadzki (wywiad z J. Miodkiem), Kibice na Ślaskim nie zrobili wiochy, „Gazeta Wyborcza” z 01.06.2006 r., s. 34 . 
It was a deserved divine punishment in Moscow and in London. Kozakiewicz won in Moscow, Russians won in London. However, it was not shown the legendary gesture of Władek. That's a pity. These shameful whistles of Polish audience had to set the volleyball fans all over the world against Polish team"26.

The most daunting may prove to be the noisy fans gadgets. As is well known doping should be positive, mainly powered by the throat and diaphragm in the form of singing and shouting, supplemented by steady clapping hands, beating applause etc. That is an ideal world of fans and is a dream of all the players. Unfortunately, depending on the sport there is no lack of kitsch inventions in the form of plastic trumpets and gas, sound batons, manual sirens, whistles, bells, rattles, ratchets. The World Cup in South Africa are remembered mainly due to sounds of vuvuzela. It was created an entire industry and Chinese manufacturers got profits in millions of juans. Earplugs were selling better than a string for balers during haymaking. The mass media were buying special headphones for announcers. The sound technicians started to work on production of the device to protect ears, as high sound pressure levels at close range can lead to permanent hearing loss for unprotected ears. Association of the vuvuzela supporters „Krzyżacy” organized a contest for a slogan designed to discourage the trumpeters to show off. The action was a success, there were 1800 voters and 450 proposals. The slogan under the title: "Moto Arena without trumpets" was chosen to be the best. There were also other proposals: "Love in the heart, a fire in the soul and you blow the trumpet in somebody's ear", "You won't fall into disfavor with somebody if you leave the trumpet at home", "Why do you blow the trumpet in the stands if everyone can cry", "Don't blow the sounds of trumpet you don't like".

They called on the Polish national volleyball players to leave trumpets at home and bring healthy throats and good humor, because the clatter of trumpet deconcentrates more than cheers. The seller of colorful trumpets from Rzeshow supermarket under the name Podprom was expelled from the stands.

It was mentioned in the introduction that the atmosphere around the retina is not conducive to bullies. The unique situation took place in Czestochowa, where local media reported on football hooligans in the volleyball hall (AZS Czestochowa) and usage of vulgarisms. After the semi-final of the World League in Sofia the crowds of Bulgarian football hooligans waited at the hall for the Polish volleyball players and only after the police arrival the last could safely leave the facility. During the meeting the hooligans threw lighters, papers and plastic cups on the floor.

An online bully is a hooligan of another category, he can also harm the competitor. Dorota Świeniewicz, the best Polish volleyball player, gave up the game for the Polish National Team, because of Internet attacks. She wrote on her website the following: "I have never had pretensions to professional and impartial criticism, but manic attack of me finally brought the results. I assure you, that physically there is nothing wrong with me, but my mentality is no longer sufficiently resistant to stress" 27 . Due to the above situation, the most important Polish media began to lead the online discussion among the publicists "Who garbage in the network." The philosopher of religion prof. Zbigniew Mikołejko wrote in the Newsweek: "The nature of the Internet lynching in the world is the same. The first scathing

\footnotetext{
${ }^{26} \mathrm{http} / / /$ wyborcza.pl/1,76842,12284482,Olbrychski__Haniebne_zachowanie_polskich_kibicow__ list_html\#ixzz2v09xv7BU.

${ }^{27} \mathrm{http}: / /$ siatkowka-subiektywna.blogspot.com/2009/08/zaskakujaca-decyzja-doroty-swieniewicz. html.
} 
comment is of great importance and matters much. It appoints a clue. It will be quickly added by another comments. In a certain period of time the victim appears to be not very needed, only the rivalry among the Internet users is taken into consideration. And the most important thing is who will be crueler. Unfortunately, the violence mechanism looks like that" 28 .

It is also worth mentioning the situation in Rzeszow referring to fans. The Resovia fan reported for the monthly „To My Kibice!” the events, which took place in December 2003:

"On Wednesday we had a volleyball Resovia match - Energy Sosnowiec, which took place exceptionally in the sports hall of Podprom. We gathered in the park, there were about 90 people of us. We were walking towards Podprom without the police. Not far from the hall one could see about 50 hooligans of the Stal team. It started the fight in the street. After a certain period of time the hooligans of the Stal were beside themselves. They were kicked. About 60 hooligans from Resovia took part in the fight. We surely were the winners. The Stal hooligans threw stones at the beginning and several of them had the belts in their hands. We had only one hammer. It was a cool fight without any equipment. I would like to have such situations as much as possible".

The above situation resulted from many reasons. After World War II Rzeszow was divided into townspeople and intellectual ones, who were Resovia fans; while workers and peasants of Rzeszów were the fans of Stal. The stadium of the Stal was initially on the outskirts of the city, the football players were not from Rzeszów, the employees and the fans were often unskilled villagers. In addition, a new club at Obrońcy Stalingradu Street was associated with new communist authorities, and after the war it was forbidden to use the traditional name Resovia. One of the oldest Polish clubs had the name Ogniwo. There were also attempts to unite two clubs under the name of Stal. It is also worth noting, that the FAC was levying dues from tens of thousands of the employees in favor of the Sports Club of the company. The club was much richer than the rivals and it also bought professional players of the Resovia, such situation led to other animosities.

It is worth mentioning that, in addition to being interested in football, the fans were also keen on basketball and volleyball (Resovia) and a speedway (Stal). Hence, the Resovia fans did not support only the football players at the stadium, but they also supported the volleyball and basketball players at the Rosir sports hall (only one ticket booklet was valid). The fans gave also support at the meetings, which were out of town, especially during basketball matches; unfortunately it also caused disturbances at the halls in Tarnów and Przemyśl. The games in 1986-1987 were the historic ones, it was the year when the Resovia team played for the European Cup. While playing with Turkish Filament Bursa and Romanian Dinamo Bucharest, the volleyball players lost the game with the score 3:0. During the third set of the match with Romanians the game was interrupted, because of the floor, which was too slippery and the players wiped the pitch with their own tracksuits. The match would have been finished if the audience had left the stadium.

Not only the place of the match is of great importance for a supporter. It becomes safer at the grandstands from year to year, so there is a turf war in the neighborhoods of the city and the surrounding villages. It should be noted that the fans do not only lay claims to the territory where the match should take place ${ }^{29}$. They are not satisfied only with

28 „To My Kibice” 2003, nr 12.

29 T. Sahaj, Fani futbolowi. Historyczno-spoteczne studium zjawiska kibicowania, Poznań 2007, s. 149. 
having advantage at the stadium, so they try to gain supremacy at a larger territories of the city $^{30}$.

The Stal housing estate: Nowe Miasto, Paderewskiego, Baranówka IV, Słocina, Dąbrowskiego, Drabiniaka, Piastów, Staromieście, Budziwój, Biała.

The Resowia housing estate: Śródmieście, Kmity, Krakowska Południe, Króla Stanisława Augusta, Baranówka I, II, III, 1000-lecia, Projektant, Sportowa, Pułaskiego, Przybyszówka.

Currently, while going to the match to the Podprom sports hall, the Resovia fans do not wonder anybody; the current situation is sustainable, though it was an unusual situation at the beginning.

Considering the volleyball fans of Resovia, it should be noted, that during their meetings they are positively treated (behave in a proper way). As an example of football fans, many volleyball supporters in Poland go with their teams. In 2004, the Association of Volleyball Fans - "Resovia" was established, the members of the club travel all over the country and abroad; recently they covered the distance over 100 thousand kilometres (the longest oneway trip to Italy $-1800 \mathrm{~km}$ ).

One of the main reasons for a good atmosphere and mobility is the fact, that the Fan Club, which is supported by the Resovia fans, takes care of getting good relations in the sports hall. It is enough to look through the song-book of a football fan and a volleyball fan of Resovia to note a similar repertoire, and even come to the conclusion, that most of these songs are originated from the football stadium. The main difference lies in the fact that there is a lack of songs with invectives in the volleyball sports hall.

The above songs are the core repertoire of Resovia soccer fans. It should be also emphasized that the voleyball fans of Resovia do not mention in their songs the sponsor of Asseco and in two cases appear such words as CWKS. As it was noted by Piotrek: "We, as fans should keep the traditions, we are not going to give them up.. The name for CWKS Resovia is preserved, is the same and will be the same".

The upholding of the above traditions was visible during the action designed to preserve the name of Resovia. It was said the following ${ }^{31}$. "We, fans of Asseco Resovia gathered together in the SSPS living in Rzeszow, in Podkarpacie and in other towns in Poland and abroad and those who support recently and those who remember the success of Rzeszow volleyball in former years, we express our deep concern about the disputes over the name of our club. The recent success of Asseco Resovia are a prime example how to combine the traditions with modern life. We are aware that it would be more difficult , on the one hand, without reference to great traditions of Resovia concerning the success and fans; on the other hand, it would not be possible without the involvement of the sponsor, that is, Asseco company".

Football fans and volleyball fans have similar likes and dislikes due to the so-called agreements. The Resovia fan under the nickname Abdul wrote the following 32 : "As for the situation with volleyball fans, before the final matches Resovia has completely broken off the friendly contacts with the Skra and now we have official relationship. We still get on well with "Jastrzęb" as it was demonstrated, by the way, during the Polish Cup, where we supported side by side (it has been already written about it). The others have also changes.

\footnotetext{
${ }^{30}$ Ibidem.

${ }^{31} \mathrm{http}: / /$ www.petycjeonline.com/apel_w_sprawie_zachowania_nazwy_asseco_resovia_rzeszow.

${ }^{32} \mathrm{http}$ ://forum.kibice.net/viewtopic.php? $\mathrm{f}=1 \& \mathrm{t}=68 \&$ start $=2200$.
} 
Zaksa volleyball team have good relations with Skra team (they established contacts in Rzeszow at the final Polish Cup and I think they will be maintained in the current season). The Skra fans cheered from the Zaksa sector at the Polish Cup. Chemik Bydgoszcz club probably made an agreement with AZS Olsztyn club. I think so, because in Rzeszow there were supporters both in the colors of Bydgoszcz and AZS".

Taking into account a good position of the Resovia fans, one can also state several incidents that have been more or less publicized by the media. One can mention a racist scandal among the Resovia fans. The daily newspaper "Nowiny" wrote: "Magdalena Onyenandu and her husband were forcibly turned out from the sector of the Resovia fans. What was the reason? Magda's husband is a Negro man. »Leśni « (Resovia football hooligans) call and say to take him out! I told them that they have nothing to do with my husband. Mirek said that he was ordered to do it" ${ }^{33}$. They had to apology after the incident, but there was a disgust.

As it was already mentioned, the support of the professional players laid in whistling at the players by the contest team in the sport hall. Not everyone was satisfied with the situation.

Adapter: "I am not a fan of Zaks, but of Delecta team, I am not here to support one or another team, but it should be admitted, that Resovia has the loudest and the rudest audience I have ever seen in Polish volleyball; they are sometimes worse than football fans; it is one thing to support the players and another thing to be a bloody idiot" 34 .

$\sim$ tsa: People, every a self-respecting volleyball fan knows that in Rzeszow there is no enjoyment from the game, there is only a whistle and wailing and the commentators do not say anything about it, because they don't want to have enemies, as everyone knows that the situation is worse during the volleyball game than at the football match; you will see the situation during the third match in Kresow, Zaksa fans will even whistle and wail, it is a normal thing for them! $!^{35}$

$\sim$ XD: "I'm just waiting that Resovia team will have to play on an empty arena, because of its fans'rudeness, .. maybe then they will understand" 36 .

Kaczmar: And you take some water during match in Podprom, because your throats will be dry as you will whistle during the whole match and you must have saliva to spit on the opponents: $)^{37}$.

There was also some dissatisfaction, because of fans behavior during the match:

"Watching the game in front of a computer screen, I heard the fans, shouting at commissars during video verification. They were Resovia fans, because such situations were also in cases with the Skra team. Their yelling was not polite, neither for them nor for people watching the game on TV or on the Internet" ${ }^{38}$.

\footnotetext{
${ }^{33}$ M. Froń, Rasistowski skandal na meczu Resovii, ,Nowiny” z 20.03.2008, s. 1.

${ }^{34} \mathrm{http} / / /$ eurosport.onet.pl/siatkowka/plus-liga/plusliga-zaksa-sprowadzila-asseco-resovie-na-ziemiewalka-o-tytul-trwa/qn9wj.

${ }^{35} \mathrm{http} / /$ www.plusliga.pl/news/id/7115/title/ZAKSA-prowadzi-w-walce-o zloto/csort/creationDate/ corder/desc/cpage/59.

${ }^{36}$ Ibidem.

37 Ibidem.

38 www.blogi/paulaxj/2011/10/jak_chamstwo_kibicow_moze_zepsuc_piekne_widowisko_jakim_ jest_mecz_siatkowki_?v=1\&obxx=218134\&order=najfajniejsze\&page $=2$.
} 
There have also been other controversies during the matches with Skra. On requests for challenge, the supporters were yelling for Mariusz Wlazły "buffoonery", "Mariusz challenge", "cry out". A famous volleyball player mentioned that fans can cause pain and mobilize "more the inscription of Resovia fans ["Game Over"], than the defeat itself. You can always lose, it is a sport. Even a favorite can lose, it's normal. That inscription motivated us, because the fans of both clubs are quasi-good friends, but such things should not be done" 39 .

Despite a few unfavorable situations, one can often hear about the Resovia volleyball fans such definitions as: amazing, exceptional, indescribable, fantastic, those who create a real spectacle and make the best atmosphere in Podprom.

$$
* * * * *
$$

The aim of the article is to describe sport events, making particular emphasis on such kind of sport as a volleyball. One should take into account the reasons due to which football fans, as well as speedway fans or hockey fans cause troubles for organizers; and there are such kinds of sport that serve as an example of fans behavior. One should take into account, that in scientific or journalistic discussion some sport arenas are described as places where people keep calm; but there are arenas, where exists anxiety. Why is there a stadium crime and does not occur the indoor crime, or it occurs rarely?

Describing the behavior and experiences during a match, it worth comparing the participants of various kinds of sport in an international context and to distinguish the supporters of different clubs.

The evaluation of "wonderful" volleyball audience by activists, athletes, journalists and spectators make difficulties for researches. How to provide empirical ranking verifications of fans in the world and assess where is the best atmosphere of the match? Due to the number of sold tickets, vouchers, original gadgets, diversity of repertoire and singing, the number of trumpets and makeup faces in the stands, or due to permission for whistling and humming at the same time? And finally, is "Małyszomania" the same as "siatkówkomania?" Can we talk about fashion, fans of success or true fans who are with their national team or club, while losing and not achieving the success?

It seems to be also important to show the change in the behavior of fans at the example of Rzeszow and Resovia, where there has been appeared the division for soccer fans and volleyball ones; it is also important if we can find common characteristics, uniting the above mentioned sports, or on the contrary, if we show a significant difference, due to media and public.

\section{REFERENCES}

[1] Banach A., O kiczu, Kraków 1968.

[2] Bryant J., Przyjemność widza a przemoc $w$ telewizyjnych transmisjach sportowych [w:] A. Gwóźdź, Media - eros - przemoc. Sport w czasach popkultury, Kraków 2003.

[3] Burszta J., Sekuła E.A., Smacznego [w:] Kiczosfery wspótczesności, red. J. Burszta, E.A. Sekuła, Warszawa 2008.

[4] Froń M., Rasistowski skandal na meczu Resovii, „Nowiny” z 20.03.2008 r.

\footnotetext{
${ }^{39} \mathrm{http} / / / w w w . s p o r t . p l / c e l e b r i t i e s / 1,87133,7464325$, Mariusz_Wlazly_o_kibicach_Resovii_Takich_ rzeczy_sie.html.
} 
[5] http://eurosport.onet.pl/siatkowka/plus-liga/plusliga-zaksa-sprowadzila-asseco-resovie-naziemie-walka-o-tytul-trwa/qn9wj.

[6] http://forum.kibice.net/viewtopic.php?f=1\&t=68\&start=2200.

[7] http://szwarcman.blog.polityka.pl/2007/11/18/czas-na-nauke-dopingu/.

[8] http://www.arc.com.pl/image/www/2012_02_02_Oblicza_polskiego_sportu_Sponsoring_ Monitor_2012_2013.pdf.

[9] http://www.petycjeonline.com/apel_w_sprawie_zachowania_nazwy_asseco_resovia_ rzeszow.

[10] http://www.plusliga.pl/news/id/7115/title/ZAKSA-prowadzi-w-walce-o zloto/csort/ creationDate/corder/desc/cpage/59.

[11] http://www.sport.pl/celebrities/1,87133,7464325,Mariusz_Wlazly_o_kibicach_Resovii_ Takich_rzeczy_sie.html.

[12] http://www.sportfan.pl/artykul/sport-na-drugim-planie-fani-kochaja-kicz-a-ty-komentarz1889\#.

[13] http://wyborcza.pl/1,76842,12284482,Olbrychski_Haniebne_zachowanie_polskich_ kibicow_list_.html\#ixzz2v09xv7BU.

[14] Kowalczuk P., Viagra dla kibiców, „Rzeczpospolita” z 22.09.2013 r.

[15] Kowalski R., Potomkowie Hooligana. Szalikowcy. Społeczno-kulturowe źródta agresji widowni sportowych, Torun 2000.

[16] Łapicki A., Nic się nie stało, Warszawa 2010.

[17] Osęka A., Mitologie artysty, Warszawa 1975.

[18] Ostrowski A., Telewizyjna transmisja sportowa, czyli największy teatr świata, Wrocław 2007.

[19] Piotrowski P., Szalikowcy. O zachowaniach dewiacyjnych kibiców sportowych, Torun 2000.

[20] Porzęcka M., O złej sztuce, Warszawa 1998.

[21] Sahaj T., Fani futbolowi. Historyczno-społeczne studium zjawiska kibicowania, Poznań 2007.

[22] Stomma L., Futbol dla milionów [w] J. Ciechowicz, W. Moska, Futbol w świecie sztuki, Gdańsk 2012.

[23] Szwarcman D. (wywiad z K. Dębskim), Wolniej panowie wolniej, „Polityka” z 03.09.2005 r.

[24] ttp://siatkowka-subiektywna.blogspot.com/2009/08/zaskakujaca-decyzja-dorotyswieniewicz.html.

[25] „To My Kibice” 2003, nr 12.

[26] Welsch W., Sport - przez pryzmat estetyki, a nawet widziany jako sztuka? [w:] Media - eros - przemoc. Sport w czasach popkultury, red. A. Gwóźdź, Kraków 2003, s. 326.

[27] www.blogi/paulaxj/2011/10/jak_chamstwo_kibicow_moze_zepsuc_piekne_widowisko_ jakim_jest_mecz_siatkowki_?v=1\&obxx=218134\&order=najfajniejsze\&page=2.

[28] Zawadzki P. (wywiad z J. Miodkiem), Kibice na Śląskim nie zrobili wiochy, „Gazeta Wyborcza” z 01.06.2006, s. 34.

\section{RÓŻNE OBLICZA KIBICÓW I AREN SPORTOWYCH}

Kibice posiadają własne wartości i cele, świadomość odrębności i nieformalną organizację wewnętrzną. Stanowią grupę opartą na styczności bezpośredniej i osobistej, w dużym stopniu angażują się emocjonalnie i identyfikują z grupą. Fani są interesującym tematem badawczym. Ulegają przemianom, rozwijają się i przekształcają. Są to grupy niepokojące i wielobarwne, szokują i fascynują, budzą niepokój i zakłopotanie. Zapewne każdy z nas słyszał o ekscesach kibiców. Przez ich postępowanie wiele osób ucierpiało na zdrowiu i życiu, zniszczone zostało 
mienie prywatne i publiczne, uległo destabilizacji życie publiczne i sportowe. Jednak kibice siatkarscy są zupełnie inni, stanowią niewątpliwie fenomen kibicowania wzorowego. Powodują, że boisko przemienia się w spektakl teatralny, ale aktorami grającymi główne role stają się kibice, a nie zawodnicy. W artykule ukazano te barwne elementy kibicowania, ze szczególnym uwzględnieniem jednych z najlepszych w Europie, kibiców „Resovii” Rzeszów. Wydaje się niezwykle ważne przedstawienie złożoności problematyki konsumenta sportowego, który przeobraża się z kibica industrialnego w kibica wrażeń sportowych. Konsumenta niezwykle trudnego, z uwagi na fakt, że wśród klienteli znajdują się fani chodzący na mecze w przypadku sukcesów. Bardzo interesująca wydaje się kwestia postrzegania zmian jakie dokonują się w sferze biznesowej i sponsoringu, gdzie rynkowe reguły przysłaniają tradycyjną, fanatyczną formę kibicowania, czyniąc z kibica nabywcę usług, najlepiej w postaci karnetów na kolejny sezon siatkarski.

Słowa kluczowe: kibice, areny sportowe, siatkówka.

DOI:10.7862/rz.2017.hss.35

Przestano do redakcji: luty 2017 r. Przyjęto do druku: czerwiec 2017 r. 
